\title{
ФЕНОМЕН РАЗРЫВООБРАЗОВАНИЯ В ДЕЛЬТОВЫХ ОТЛОЖЕНИЯХ МЫСА РЫТЫЙ НА СЕВЕРО-ЗАПАДНОМ ПОБЕРЕЖЬЕ ОЗЕРА БАЙКАЛ
}

Лунина О. В., Гладков А. А.

\author{
Аннотация \\ УДК 551.243.1 + 528.7 \\ ФЕНОМЕН РАЗРЫВООБРАЗОВАНИЯ В ДЕЛЬТОВЫХ ОТЛОЖЕНИЯХ МЫСА РЫТЫЙ НА \\ СЕВЕРО-ЗАПАДНОМ ПОБЕРЕЖЬЕ ОЗЕРА БАЙКАЛ \\ (по данным аэрофотосъемки) \\ О.В. Лунина1, А.А. Гладков1, 2
}

1Институт земной коры СО РАН, 664033, Иркутск, ул. Лермонтова, дом 128

2 Детский технопарк "Кванториум Байкал" ГАУ ДО ИО "Центр развития дополнительного образования детей"

\section{АННОТАЦИЯ}

Представлены материалы аэрофотосъемки мыса Рытый - уникального и самого загадочного места на северо-западном побережье озера Байкал. Аэрофотосъемка проведена с помощью БПЛА DJI Phantom 4 Pro V2.0, в результате чего составлены ортофотоплан и цифровая модель местности площадью 11,074 км2. При дешифрировании полученных изображений в дельтовых отложениях р. Риты, слагающих мыс, обнаружены нарушения земной поверхности, простирающиеся на север и северо-восток в 30-150 м от берега оз. Байкал. Разрывы представляют собой четко локализованную зону общей протяженностью 2,9 км. Выполненный анализ показал, что особенности строения зоны подчиняются общим закономерностям развития разломов земной коры, сформированных в результате преобладающего растяжения. Установлено, что образование разрывов предопределено тектоникой и является вторичным эффектом резонансных колебаний от землетрясения 13.08.1962 г. с M=5.2, эпицентр которого находился в $\square 35$ км от мыса Рытый на юговосток, в зоне Морского разлома. Сейсмическое событие инициировало формирование зоны разрывов, после чего произошло гравитационное проседание грубообломочных отложений конуса выноса в прибрежной зоне. Сделан вывод о том, что развитие современных геоморфологических форм в периферийной части конуса выноса р. Рита на суше подобно образованию подводного рельефа в районе дельты р. Селенги и происходит под действием ведущих рельефообразующих факторов - сейсмогенного разрывообразования и следующих за ним гравитационных смещений, которые усиливаются в водонасыщенной среде и впоследствии осложняются эрозионными процессами.

Ключевые слова: зона разрывов, уступ, параметры, аэрофотосъемка, БПЛА, ортофотоплан, цифровая модель местности, мыс Рытый, озеро Байкал

THE RUPTURING PHENOMENA IN THE DELTAIC DEPOSITS OF THE CAPE OF RYTY ON THE NORTHWEST COAST OF LAKE BAIKAL)

(based on aerial photography data) 
O.V. Lunina1, А.С. Гладков1, 2

1 Institute of the Earth’s Crust, Siberian Branch of Russian Academy of Sciences,

664033, 664033, Irkutsk, Lermontova street, 128

2 Center for the Development of Continuing Education of Children» Ministry of Education of Irkutsk Region

\section{ABSTRACT}

The article presents materials of aerial photography of the Cape of Ryty - a unique and most mysterious place on the northwestern coast of Lake Baikal. Photogrammetric survey was carried out using a DJI Phantom 4 Pro V2.0 UAV, resulting in an orthophoto and digital terrain model with an area of 11.074 $\mathrm{km} 2$. When deciphering the images obtained in the Rita River deltaic sediments, which compose the cape, surface ruptures trending north and northeast at 30-150 $\mathrm{m}$ from the shore of the lake Baikal were discovered. The ruptures represent a clearly localized zone with a total length of $2.9 \mathrm{~km}$. The performed analysis showed that the structural features of the zone obey the general laws of the development of faults, formed as a result of prevailing extension. It is established that the formation of the ruptures is predetermined by tectonics and is a secondary effect of resonant oscillations from the earthquake of 08.13.1962 with $M=5.2$, the epicenter of which was located $\square 35 \mathrm{~km}$ from the Cape of Ryty to the southeast, in the the Morskoy damage fault zone. The seismic event initiated the formation of the surface ruptures, after which a gravitational subsidence of coarse deposits of the fan in the coastal zone occurred. It is concluded that the development of modern geomorphological forms in the peripheral part of the fan of the Rita River on land is similar to the formation of an underwater topography in the region of the Selenga River delta. It occurs under the influence of the seismogenic rupturing and following gravitational movements, which intensify in a water-saturated environment and are subsequently complicated by erosion processes.

Key words: rupture zone, scarp, parameters, aerial photography, UAV, orthophoto, digital terrain model, Cape Ryty, Lake Baikal.

\section{Ключевые слова:}

зона разрывов, уступ, параметры, аэрофотосъемка, БПЛА, ортофотоплан, цифровая модель местности, мыс Рытый, озеро Байкал 


\title{
ФЕНОМЕН РАЗРЫВООБРАЗОВАНИЯ В ДЕЛЬТОВЫХ ОТЛОЖЕНИЯХ МЫСА РЫТЫЙ НА СЕВЕРО-ЗАПАДНОМ ПОБЕРЕЖЬЕ ОЗЕРА БАЙКАЛ
} (по данным аэрофотосъемки)

\author{
О.В. Лунина ${ }^{1}$, А.А. Гладков ${ }^{1,2}$ \\ ${ }^{1}$ Институт земной коры СО РАН, 664033, Иркутск, ул. Лермонтова, дом 128 \\ ${ }^{2}$ Детский технопарк "Кванториум Байкал" ГАУ ДО ИО "Центр развития дополнительного \\ образования детей"
}

\section{ВВЕДЕНИЕ}

Мыс Рытый - уникальное и самое загадочное место на северо-западном побережье озера Байкал (рис. 1-2). Сведения о нем, как о геологическом объекте, можно найти в научно-популярных изданиях [Бурмейстер, Костюнин, 2006; Карнышев, 2010] и на страницах интернета. Мыс образован дельтовым, преимущественно грубообломочным, аллювием р. Риты, которая часто меняет свое русло, формируя рытвины. Именно поэтому эта выдающаяся острым углом суша и получила свое мистическое название. Протяженность мыса в северо-восточном направлении составляет 4.32 км, в северозападном 1,68 км.

На мысе Рытом отмечается аномальное магнитное поле и повышенные остаточные изостатические аномалии силы тяжести [Бурмейстер, Костюнин, 2006], следы мощных селей и оползневые деформации вдоль сейсмогенных разрывов. По распределению потока глубинного тепла прилегающая территория озера относится $\mathrm{k}$ КочериковоЗаворотнинским тепловым аномалиям [Голубев, 2008], однако, по устному сообщению В.А. Голубева, как раз напротив мыса Рытый тепловой поток через дно оз. Байкал невысокий и находится в пределах 40-50 мВт/м². Капитаны судов отмечают, что, проходя мимо мыса Рытого время от времени пропадает сигнал GPS. B ходе полевых работ, мы также столкнулись с подобной проблемой. Беспилотный летательный аппарат (БПЛА) во время аэрофотосъемки дважды терял связь с пультом управления, и один раз значения координат в точке наблюдения обнулились на экране ручного навигатора, чего ранее в авторской практике никогда не было. Примечательно, что при замерзании Байкала из года в год регулярно появляется становая трещина параллельно береговой линии мыса Рытый.

Согласно геологической карте [1974], через мыс Рытый проходит две линии тектонического контакта, погребенные под молодыми отложениями (рис. 3), а в 
прилегающих коренных породах - мощная до 2,5 км зона милонитизации и катаклаза. На схемах в работах [Сейсмотектоника, 1968; Чипизубов и др., 2003] главный сейсмогенный разлом показан по северо-западной границе дельтовой равнины. По А.В. Чипизубову и др. [2003] соответствующий ему уступ относится к палеосейсмодислокациям 3 возрастной группы с возрастом 6-8 тыс. лет и углами склона 24-29. Серия более коротких разрывов также картируется в Байкальском хребте. На левом побережье р. Риты описан «сейсмогравитационный тектонический клин» с амплитудой вертикального смещения до 400 м [Сейсмотектоника, 1968], но сейсмогенная природа подобных форм рельефа не была признана последователями.

Первоначальной задачей наших исследований были палеосейсмогенные разрывы, частично описанные в более ранних работах [Сейсмотектоника, 1968; Чипизубов и др., 2003]. Однако после обработки материалов беспилотной аэрофотосъемки вблизи береговой линии озера Байкал на мысу Рытом нами была выявлена зона нарушений, которая заслуживает специального исследования, так как представляет собой феномен современного разрывообразования в Байкальской рифтовой зоне. В связи с этим цель настоящей работы заключается в представлении первых результатов картирования и морфоструктурного анализа обнаруженных разрывов для выявления возраста и природы их возникновения в молодых дельтовых отложениях.

Проблема изучения деформаций в дельтовых отложениях рек имеет важнейшее значение для выявления позднеголоценовых и современных смещений земной поверхности. Речные дельты очень изменчивы [Михайлов, 2002], а значит сохранившиеся в их пределах деформации являются наиболее молодыми следами тектонических движений. Влияние тектонических деформаций на реки и дельты зависит от характеристик водотоков, кинематического типа разломов и их ориентации в речной системе [Miall, 1981]. Эффекты могут включать смещенные русла, отмершие и обезглавленные каналы (beheaded channels), изменения извилистости, подпруживание, изменение скорости эрозии [Keller et al., 1982; Rockwell et al., 1984; Schumm, 1986; Johnston, Schweig, 1996; Leeder et al., 1996; Peakall, 1998; Kim et al., 2010; Martin, 2012; Blanton et al., 2020]. Обнаружение следов тектонических движений возможно, когда скорость формирования и величина наклона разломного уступа достаточно большие для того, чтобы перевесить влияние седиментации, эрозии и уклона реки [Holbrook, Schumm, 1999; Kim et al., 2010]. Поднятие (или опускание) одного блока в дельте эффективно снижает базовый уровень. В ответ, уклон реки увеличивается и для поддержания ее градиента основное русло может начать врезаться глубже. В другом случае может 
усилится извилистость водного потока [Schumm, 1993] и даже произойти перестройка речной системы.

В дополнении к основному содержанию статьи, особую ее ценность представляет ортофотоплан мыса Рытый, выполненный с точностью 6-10 см/пикс, и фиксирующий геоморфологическую обстановку на 30 июня - 5 июля 2019 г.

\section{МЕТОДЫ ИССЛЕДОВАНИЙ}

Исследование мыса Рытый проводилось аэрофотограмметрическим методом, который включал аэрофотосъемку и обработку материала с целью получения детального ортофотоплана и цифровой модели местности (ЦММ). Аэрофотосъемка проводилась с помощью БПЛА DJI Phantom 4 Pro V2.0, который оснащен камерой с 1-дюймовой матрицей CMOS с разрешением 20 Мп и механическим затвором, позволяющим избежать искажений изображения. Улучшенная матрица, оптимизированный широкоугольный объектив с диафрагмой f/2.8 и технология обработки обеспечили достаточно высокую детализацию фото с реалистичными цветами.

В пределах сравнительно ровного рельефа на мысе управление беспилотным летательным аппаратом выполнялось в автоматическом режиме. Для создания полетных заданий мы использовали официальное приложение фирмы DJI «GroundStation Pro», которое позволяет строить оптимальные полетные миссии и сохранять данные в облачном хранилище, обеспечивая тем самым надежное и точное выполнение задач. Данное приложение работает только под управлением операционной системы «iOS», устанавливаемой на смартфонах и планшетах производства фирмы «Apple». В связи с этим нами дополнительно применялся программный продукт «Litchi», который позволяет осуществлять разработку полетных заданий с использованием смартфона/планшета под управлением операционной системы «Android», в том числе без наличия стабильного доступа к сети Интернет. На участках со сложным рельефом, характеризующимся резкими изменениями высотных отметок, задействован ручной вариант управления, что связано с высоким риском потери БПЛА в автоматическом режиме.

Высота полета составляла не более 120-150 метров относительно земной поверхности при скорости полета не более 30 км/час, что соответствует получению цифровых моделей местности/рельефа и ортофотопланов с сверхвысоким пространственным разрешением 3-10 см/пиксель [Кадничанский, 2013]. Геодезическая привязка полученных картографических материалов (цифровых моделей местности и ортофотопланов) осуществлялась с использованием координат центров фотографирования, зафиксированных встроенным GPS-приемником используемого 
БПЛА, и наземных опорных точек (маркеров), распределенных по береговой и центральной частям мыса Рытый. По итогам аэрофотосъемки, проводимой 30 июня, 1 и 5 июля 2019 г. было получено более 7000 фотографий, обработанных по единой методике.

Для обработки изображений земной поверхности мыса Рытый использовалось лицензионное программное обеспечение «Agisoft Metashape». Стандартно обработка проводилась в несколько этапов [Тихонов, Аакматов, 2018; Agisoft Metashape, 2020]: (1) загрузка фотографий; (2) выравнивание фотографий; (3) оптимизация выравнивания; (4) построение плотного облака точек, сопоставимого с облаками точек LIDAR при проведении лидарной съемки; (4) создание карты высот, которая представляет собой цифровую модель местности/рельефа и строится на основании данных облака точек или полигональной модели; (5) создание ортофотоплана путем совмещения близлежащих снимков и определения соответствия точек; (6) экспорт полученных результатов в форматы GeoTIFF и *.jpeg.

Полученные ортофотоплан (рис. 4) и цифровая модель местности (рис. 5) были отдешифрированы, в результате чего помимо известных палеосейсмогенных разрывов в Байкальском хребте и в месте сочленения тыловой части дельты р. Риты с его склоном, у берега оз. Байкал обнаружена молодая зона нарушений. Поскольку конус выноса р. Риты слабо покрыт растительностью, а отдельно стоящие деревья хорошо различимы на изображениях, ЦММ, по аналогии с ЦМР, применялась для анализа рельефа и морфоструктурного анализа выявленных уступов.

За максимальное вертикальное смещение по разрыву (throw) принималось значение высоты разломного уступа на наиболее представительном сегменте разрыва, измеренное от верхней до нижней бровки уступа (рис. 6), по аналогии с работой [Wilkinson et al., 2015]. При значительном уклоне нарушенной исходной поверхности реальное смещение получается преувеличенным, но такой экспресс-подход приемлем для быстрой оценки смещений [McCalpin, 2009], тем более в протяженных конусах выноса, где средний уклон, как правило, менее $5^{\circ}$. В случае горизонтальной исходной поверхности, нарушенной разломом, высота уступа и вертикальное смещение равны. Перпендикулярно простиранию разрыва измерялась горизонтальная компонента полного смещения по падению разрыва, т.е. горизонтальное разобщение исходной поверхности (heave, рис. 6). Для всех разрывов также были измерены простирание, длина, наклон исходных поверхностей, угол и азимут падения уступа. В случае явно выраженного рва, определялись его глубина и ширина. В итоге для установления закономерностей распределения разрывов полученные параметры статистически проанализированы. 


\section{РЕЗУЛЬТАТЫ ИССЛЕДОВАНИЙ}

Ортофотоплан и цифровая модель местности мыса Рытый. Технические возможности нашей графстанции (Intel Core i9-10940X/GIGABYTE X299 UD4 Pro/8*16Gb DDR4/ 500Gb SSD M.2/2*8Tb HDD/850W/) позволили получить ортофотоплан и ЦММ мыса Рытый и окрестностей с пространственным разрешением 6-10 и 10-20 см/пиксель, соответственно. Отснятая площадь составила 11,074 км² (рис. 4). Четыре небольших фрагмента внутри территории оказались неохваченными аэрофотосъемкой, но это не повлияло на получение данных о поверхностных деформациях мыса Рытый, и в целом критически не сказывается на получении итогового результата. Суммарная площадь «белых пятен» 0,064 км² составляет всего 0,58 \% от всего района аэрофотосъемки. Площадь самой дельты равна 4,791 кв². На ортофотоплане хорошо видно место, где водоток р. Риты уходит под землю.

Полезную геологическую информацию и геоморфометрические параметры можно извлечь из ЦММ (рис. 5). На выходе р. Риты из гор, в бортах ее долины сохранился слабо окатанный крупнообломочный и плохо сортированный материал с большим количеством песка и суглинка (рис. 2), генезис которого требует дополнительных исследований. На геологической карте он отнесен к верхнечетвертичным галечникам и пескам (рис. 3). Морфологически эти отложения представляют собой фрагменты древнего конуса выноса, местами перекрытые молодыми наносами временных водотоков и сменяющиеся ниже по течению реки современными аллювиальными образованиями. По высоте древнего конуса выноса, измеренного на ЦММ на участках отсутствия деревьев и густой растительности в правом и левом бортах р. Риты можно сделать вывод, что видимая мощность отложений, соответствующих первому циклу конусообразования, достигает 40-43 м. Судя по разнице высот на гипсометрическом профиле $\mathrm{CD}$, мощность отложений более позднего второго цикла в центральной части дельтовой равнины достигает 56 м. Средний уклон поверхности по линии АВ составляет $3^{\circ}$, максимальный - $18^{\circ}$ (рис. 5).

Современные разрывы мыса Рытый. Обнаруженные при дешифрировании ортофотоплана и ЦММ нарушения земной поверхности представляют собой четко локализованную зону разрывов шириной до 135 м, расположенную в 30-150 м от берега оз. Байкал и простирающуюся с перерывами на север и северо-восток на протяжении 2,9 км (рис. 4). Преобладающее направление разрывов - 30-60 (рис. 7). Нарушения представляют собой уступы (иногда с рвами в их подножии), высотой на наиболее выразительном сегменте, ассоциируемой с вертикальным смещением, от 0,2 до 1,84 м. Уклон нарушенной исходной поверхности в большинстве точек измерений не более $4^{\circ}$, единичные замеры достигают 7-9. В нескольких местах зона полностью эродирована 
водными потоками. В целом она повторяет озерный край дельты, но по строению соответствует классической зоне растяжения, возможно с незначительной сдвиговой компонентой, хотя однозначных горизонтальных смещений русел вдоль разрывов не установлено.

По простиранию вся зона разделяется на два крупных сегмента (рис. 4). Субмеридиональный простирается в северо-восточном секторе мыса Рытый, где в средней части полностью уничтожен восточным рукавом р. Риты с хорошо проработанными руслами глубиной в отдельных местах до 2,4 м. В северной части этого сегмента разрывы особенно отчетливо выражены на земной поверхности (рис. 6, 8a). Максимальные вертикальные смещения по ним колеблются от 0,33 м до 1,14 м, длины разрывов - от 17,45 до 129,6 м. На обзорном снимке (рис. 8, а), сделанном летом 2020 г. с высоты около 35 м видно, что два достаточно протяженных разрыва, откартированных по данным аэрофотосъемки 2019 г., представляют собой один разрыв, средняя часть которого на ортофотоплане и ЦММ с полученным разрешением не просматривается из-за незначительного вертикального смещения. В южной части субмеридионального сегмента два нарушения длиной 218 и 43,28 м с градиентами исходных поверхностей 1,84 и 0,76 м, соответственно, плавно переходят в северо-восточную систему разрывов.

Северо-восточный сегмент зоны представляет собой более распределенную систему нарушений длиной от 8,16 до 210 м (рис. 4). Максимально зафиксированные вертикальные смещения по ним изменяются от 0,2 до 1,14 м. На одном из участков зона частично размыта, из-за чего там сохранились только фрагменты разрывов. В целом они представлены менее контрастно на местности (рис. 8, б). но очевидно, что не все из них строго подчиняются простиранию береговой линии. Распределение длин разрывов с шагом 10 м в первом приближении показывает общую закономерность, характерную для развития разрывных сетей, которая заключается в том, что во всей зоне коротких разрывов больше, чем длинных (рис. 9, a). Самый протяженный из них - 218 м, наименьший - 8,16 м. Экспоненциальная закономерность не является идеальной, так как некоторые нарушения, в особенности самые мелкие, являются сохранившимися фрагментами более крупных разрывов.

Углы откосов уступов в дельтовых отложениях колеблются от $6^{\circ}$ до $21^{\circ}$ (рис. 9, б). Большинство из них значительно размыты, имеют углы менее $10^{\circ}$ и падение на юговосток. Несмотря на маленькие значения углов, разрывы прослеживаются на ЦММ и/или на ортофотоплане (рис. 4 и 5, 6). Низкорослая травянистая растительность в некоторых местах маркирует линейные понижения в подножиях эскарпов. Вертикальное смещение прямо пропорционально длине разрыва (коэффициент корреляции $\mathrm{R}=0.73$ ) и 
горизонтальной компоненте полного смещения по падению разрыва ( $\mathrm{R}=0.65$, pис. 10$)$. Обе составляющие подвижки, как и длина отдельных разрывов, повторяют одну и ту же закономерность: количество нарушений с меньшими величинами смещений больше (рис. 9, в-2), что означает, что значительная часть длины выявленной зоны разрывов приходится на участки со смещениями, намного меньшими, чем максимальная подвижка. Такая ситуация характерна для сейсмогенных сбросов [McCalpin, 2009].

\section{дискУссия}

Возраст формирования зоны разрывов. Первые вопросы, которые возникают при обнаружении подобной системы разрывов, - когда она образовалась и ее генезис. В архиве ИЗК СО РАН нам не удалось найти аэрофотоснимки на мыс Рытый, чтобы проанализировать изменение ландшафта одной и той же территории, спустя более 60 лет. Сравнение полученного ортофотоплана с космоснимками низкого разрешения 1984-2016 г., представленными в онлайн-сервисе Google Earth Pro, позволяет на основании четкости изображения главных русел предположить, что одно из них на северо-востоке мыса (см. восточный рукав р. Риты на рис. 4), по крайней мере, с 2000 г., перестало функционировать. В целом, судя по сохранности каналов, с 1984 по 2000 г. вынос рыхлого материала водотоками был интенсивнее, чем в последние 20 лет. На момент аэрофотосъемки вода бежала по крайней правой протоке (см. западный рукав р. Риты на рис. 4). Как было отмечено выше, восточный рукав р. Риты эродировал субмеридиональный сегмент в центральной части, следовательно, система разрывов сформировалась до 2000 г. Имеющиеся в нашем распоряжении космоснимки, полученные с KA Pleiades-1A/1B 11.06.2016 г., с пространственным разрешением 0,5 м/пиксель, позволяют констатировать, что система современных нарушений уже существовала летом 2016 г., и в целом, ландшафт территории мыса Рытого с этого времени заметно не изменился.

На карте государственной геологической съемки (рис. 3) в пределах дельтовой равнины показаны две линии тектонического контакта, погребенные под современными отложениями р. Риты. В объяснительной записке к карте [1983] нет указаний на метод картирования этих нарушений, но отмечено, что в конусе выноса р. Риты наблюдаются тектонические рвы. Из приведенного описания, неясно, какие структуры имели ввиду авторы брошюры, но на плане сейсмогенных структур, составленном В.П. Солоненко и В. Жилкиным на район мыса Рытый [Сейсмотектоника, 1968], обнаруженные нами разрывы отсутствуют. Сейсмогенный разлом, совпадающий с одной из линий тектонического контакта под молодыми осадками, показан на схеме В.П. Солоненко в вершинной зоне 
конуса выноса, в то время как обнаруженные нами разрывы расположены в его периферийной части, в 30-150 м от берега оз. Байкал. Тем не менее, мы полагаем, что вторая линия тектонического контакта на геологической карте 1974 г. издания не могла быть показана без оснований. Скорее всего, картирование разломов под молодыми осадками было выполнено на базе геофизических материалов, поэтому она чуть смещена в отложениях относительно обнаруженной нами зоны и уходит под воду. Если наше предположение верно, то система разрывов уже существовала к 23 декабря 1968 г., когда геологическая карта была одобрена Научно-техническим советом Бурятского геологического управления.

Из более ранних топографических планов, наиболее детальным является атлас озера Байкал 1908 г. издания [Дриженко, 1908]. На листе атласа 8Б, на мысу Рытом прослеживается три, действующих на то время, по крайней мере, в половодье, речных рукава, из которых центральное, разветвляющееся на два основных водотока (рис. 11), судя по слабой выраженности в современном ландшафте, давно не функционирует. Этот центральный рукав, просматриваемый на ортофотоплане 2019 г. (рис. 4), только частично размывает северо-восточный сегмент системы разрывов, что свидетельствует о том, что они образовались после 1908 г., когда упомянутые русла уже отмирали. В ином случае, они бы полностью уничтожили поверхностные нарушения. Таким образом, из приведенного анализа имеющихся данных следует, что обнаруженная нами современная система разрывов образовалась в период между 1908 и 1968 годами.

Генезис зоны разрывов. В структурном отношении современная зона разрывов расположена в 1,5 км от главного сместителя Кочериковского разлома (рис. 1). С юговосточной стороны к мысу приближается предполагаемый разлом того же северовосточного простирания, картируемый в подножии подводного уступа по батиметрическим данным ([Лунина, 2010], см. также базу данных на http://activetectonics.ru/ActTecServ.html). Последний может прослеживаться и далее на югозапад под донными отложениями авандельты р. Риты. Принимая во внимание особенности строения и активизации отдельных зон разломов шириной до нескольких км в осадках озера Байкал [Solovyeva et al., 2020], все эти упомянутые северо-восточные структуры на суше и в акватории можно рассматривать в качестве элементов одной крупной разломной системы. В 16 км на восток от мыса Рытого проходит предполагаемый меридиональный разлом, а в 10 км на юг в Байкале фиксируется вытягивание изобат в направлении на север, которое «стреляет» прямо в субмеридиональный сегмент разрывов в дельте р. Риты. Учитывая приведенные данные, следует признать, что, несмотря на очевидное совпадение 
простирания современной зоны нарушений с береговой линией мыса, ее образование предопределено тектоникой.

Исходя из пространственных особенностей проявления уступов на поверхности относительно в разной степени сохранившихся русел р. Риты, следует, что система разрывов образовалась одномоментно, а затем какое-то время могла продолжить развиваться под действием гравитационного проседания осадков в периферийной части дельты. Происходит ли этот процесс сейчас, ответить сложно без мониторинговых измерений, но учитывая, что на некоторых участках система полностью или частично эродирована, скорость просадки в последние десятки лет однозначно ниже, чем скорость эрозии и седиментации.

Таким образом, вышеприведенные факты свидетельствуют, что наблюдаемый в дельтовых отложениях р. Риты феномен связан с импульсным событием, которое имело место между 1908 и 1969 годами. Согласно статистике, эффекты разрывообразования земной поверхности в Восточной Сибири могут происходить при землетрясениях с Ms $\geq 4.8$ на определенном расстоянии от эпицентра в зависимости от силы землетрясения. Анализ данных исторической и инструментальной сейсмичности показывает, что в этот период на расстоянии до 55 километров от зоны современных разрывов произошло 3 землетрясения - 26.05.1939 с $\mathrm{M}=6.0,28.10 .1961$ г. с $\mathrm{M}=5.5$ и 13.08.1962 г. с $\mathrm{M}=5.2$ по [Kondorskaya, Shebalin, 1982] (рис. 1). Менее сильные события или сопоставимые по магнитуде, произошедшие в указанный интервал времени, расположены еще дальше, и не могут быть ассоциированы с наблюденными деформациями. Наиболее вероятно, что система разрывов могла сформироваться при ближайшем землетрясении 13.08.1962 г. со сбросовым механизмом очага и северо-восточным простиранием нодальных плоскостей [Солоненко и др., 1993]. Его эпицентр располагался прямо напротив мыса Рытый у подножия юго-восточных склонов подводного Академического хребта в зоне Морского (Ольхонского разлома), в 35 км от обнаруженной нами системы разрывов (рис. 1). Максимальное расстояние, на котором могли распространяться эффекты этого события от его эпицентра равно 113,62 км, согласно уравнению граничной кривой для явлений разрывообразовния [Лунина и др., 2014, см. табл. 1, уравнение № 6]. Связь с этим событием объясняет тот факт, что В.П. Солоненко с коллегами, картируя сейсмодислокации по аэрофотоснимкам 50-х годов, не обнаружили эти разрывы, хотя это могло быть обусловлено и плохой разрешающей способностью аэрофотоснимков тех лет. Тем не менее, мы полагаем, что образовавшаяся в дельтовых отложениях зона могла отражать вторичный эффект резонансных колебаний от землетрясения 1862 г., проявившийся в формировании системы нарушений. Исходя из уравнений регрессий 
между магнитудой и смещением, смещением и длиной сейсмогенных сбросов [Лунина, 2001, табл. 5], следует, что установленная зона протяженностью 2,9 км вполне могла сформироваться при землетрясении с магнитудой 5.2, но максимальные тектонические смещения не могли быть более первых сантиметров. Максимальная же вертикальная подвижка по одному из разрывов зоны в дельтовых отложениях достигает 1,844 м. Следовательно, достаточно большие вертикальные смещения произошли в результате гравитационного проседания грубообломочных отложений, инициированного землетрясением 1962 г.

Проведенный анализ показывает, что основными рельефообразующими факторами во фронтальной части дельты р. Риты стали сейсмичность и гравитационное смещение блоков, предопределенное тектоническим строением района исследований. Аналогичные процессы происходят в подводной части дельты р. Селенги, где по батиметрическим данным и материалам многоканального сейсмического профилирования в осадочных толщах фиксируются тектонические уступы, смещения и гравитационное оседание блоков, ассоциируемое с сейсмотектонической активизацией [Хлыстов и др., 2016].

Роль гравитационного сползания, неотектонических дислокаций и землетрясений в формировании подводных склонов озера Байкал и структуре его осадочных толщ обсуждалась и в более ранних работах [Воропинов, 1965], но ввиду недостаточных сведений о связи конкретных землетрясений с деформациями поверхности на суше и под водой вклад сейсмичности недооценивался [Замараев, 1975]. Настоящее и предыдущие исследования [Хлыстов и др., 2016] наглядно показывают, что уникальная природная обстановка экосистемы Байкала в районе авандельты р. Селенги и в прибрежной части озера на мысу Рытый формируется при воздействии одних и тех же эндогенных и экзогенных процессов, и лишь в подводной части гравитационные смещения усиливаются, благодаря водонасыщенности осадочных пластов.

\section{ЗАКЛЮЧЕНИЕ}

Подводя итоги вышеизложенному, следует выделить основные результаты проведенных исследований:

1. Впервые на основе аэрофотосъемки с использованием БПЛА получены ортофотоплан и цифровая модель местности мыса Рытый с пространственным разрешением 6-10 и 10-20 см/пиксель, соответственно. Фотографическое и цифровое изображения фиксируют геоморфологическую обстановку местности на 30 июня - 5 июля 2019 г. и могут в дальнейшем быть использованы в различных видах исследований. 
2. При дешифрировании ортофотоплана и ЦММ в дельтовых отложениях р. Риты обнаружены разрывные нарушения земной поверхности, которые представляют собой четко локализованную зону разрывов общей длиной 2,9 км и шириной до 135 м, выраженных сбросовыми уступами высотой от 0,2 до 1,84 м. Зона с перерывами простирается на север и северо-восток в 30-150 м от берега оз. Байкал, а особенности ее строения подчиняются общим закономерностям развития разломов земной коры, сформированных в результате преобладающего растяжения.

3. В результате анализа имеющихся картографических материалов и взаимоотношений речных русел со сбросовыми уступами установлено, что образование современной зоны разрывов во фронтальной части дельты р. Рита предопределено тектоникой и произошло как вторичный эффект резонансных колебаний от землетрясения 13.08.1962 г. с M=5.2, эпицентр которого находился напротив мыса Рытый, в зоне Морского разлома. Сейсмическое событие инициировало формирование системы разрывов, после чего произошло гравитационное проседание грубообломочных отложений конуса выноса в прибрежной зоне.

4. Развитие современных геоморфологических форм в периферийной части конуса выноса р. Рита на суше подобно образованию подводного рельефа в районе дельты р. Селенги и происходит под действием ведущих рельефообразующих факторов сейсмогенного разрывообразования и следующих за ним гравитационных смещений, которые усиливаются в водонасыщенной среде и впоследствии осложняются эрозионными процессами.

Аэрофотосъемка 2019 г. проведена попутно в ходе проведения экспедиционных работ ИЗК СО РАН с использованием НИС «Геолог». Исследование выполнено при финансовой поддержке РФФИ и Правительства Иркутской области в рамках научного проекта № 20-45-385001 р_Наставник, что дало возможность закупить оборудование для обработки материалов аэрофотосъемки и провести последующую их обработку и анализ. В ходе исследований для школьников - участников проекта Н.А. Михалева и Е.А. Петрова проведены специальные обучающие мастер-классы по построению ортофотопланов и ЦММ, а также продемонстрированы морфологические признаки разрывов на полученных изображениях.

Авторы благодарны ФГБУ «Заповедное Прибайкалье» за возможность проведения научно-исследовательских работ на территории Байкало-Ленского заповедника в рамках договора о сотрудничестве № 43 от 30.05.2019 г.

\section{ЛИТЕРАТУРА}


Бурмейстер А.А., Костюнин О.В. Тайны Байкала: Гневный мыс Рытый. Иркутск, ОАО НПО «Облмашинформ», 2006, 31 с.

Воропилов В.С. Морфология и геологическая структура подводного склона южного Байкала между ст. Слюдянкой и Мысовой // Геология и геофизика, 1965, № 8, с. 28-36.

Геологическая карта масштаба 1:200 000, серия Прибайкальская, лист № 49-XIX. М.: Аэрогеология, 1974.

Голубев В.А. Кондуктивный и конвективный вынос тепла в Байкальской рифтовой зоне. Новосибирск, Академическое издательство «Гео», 2008, 222 с.

Дриженко Ф.К. Атлас озера Байкал / Составлен гидрофизической экспедицией под руководством полковника Ф.К. Дриженко. СПб., Изд. Глав. гидрогр. упр., 1908, 31 л. (две сборные карты).

Замараев С.М. Гравитационный тектогенез в осадочной толще впадины озера Байкал. Круговорот вещества и энергии в озерных водоемах. Отв. ред. Г.И. Галазий, К.К. Вотницев. Новосибирск: Наука, 1975, с. 418-423.

Кадничанский С.А. Обоснование допустимой высоты фотографирования при стереотопографической съемке рельефа // Изв. вузов. Геодезия и аэрофотосъемка, 2013, № 3, с. $31-35$.

Карнышев А.Д. Байкал таинственный, многоликий и разноязыкий. Издание третье испр. и доп. Иркутск, Изд-во БГУ, 2010, 552 с.

Лунина О.В. Влияние напряженного состояния литосферы на соотношения параметров сейсмогенных разрывов и магнитуд землетрясений // Геология и геофизика, 2001, T. 42, № 9, с. 1389-1398.

Лунина О.В., Гладков А.С., Шерстянкин П.П. Новая электронная карта активных разломов юга Восточной Сибири // Доклады РАН, 2010. Т. 433, № 5, с. 662-667.

Лунина О.В., Андреев А.С., Гладков А.А. Закономерности проявления и модели локализации опасных геологических процессов при сейсмогенной активизации разломов на юге Сибири и в Монголии // Геология и геофизика, 2014, № 8, с. 1294-1313.

Михайлов В.Н. Эти изменчивые речные дельты // Природа, 2002, № 4, с. 1-10.

Объяснительная записка к геологической карте СССР масштаба 1:200 000, серия Прибайкальская, лист № 49-ХІХ. Составитель В.И. Давыдов, редактор Д.Ц. Цыренов. М.: ВСЕГЕИ - Союзгеолфонд, 1983, 75 с.

Сейсмотектоника и сейсмичность рифтовой системы Прибайкалья. Гл. ред. В.П. Солоненко. М., Наука, 1968, 220 с. 
Солоненко А.В., Мельникова В.И., Козьмин Б.М., Кучай О.А., Суханова С.С. Напряжения и подвижки в очагах землетрясений Сибири и Монголии // Сейсмичность и сейсмическое районирование Северной Евразии. Выпуск 1. М.: ИФЗ РАН, 1993, с. 113122.

Тихонов А.А., Аакматов Д.Ж. Обзор программ для обработки данных аэрофотосъемки // Горный информационно-аналитический бюллетень, 2018, №12, с. 192-198.

\section{Хлыстов О.М., Кононов Е.Е., Хабуев А.В., Белоусов О.В., Губин Н.А.,} Соловьева М.А., Наудс Л. Геолого-геоморфологические особенности Посольской банки и Кукуйской гривы озера Байкал // Геология и геофизика, 2016, Т. 57, № 12, с. 2229-2239.

Чипизубов А.В., Мельников А.И., Столповский А.В., Баскаков В.С. Палеосейсмодислокации и палеоземлетрясения в пределах Байкало-Ленского заповедника (зона Северобайкальского разлома) // Труды Государственного природного заповедника «Байкало-Ленский». Иркутск, РИО НЦ РВХ ВСНЦ СО РАМН, 2003, вып. 3, с. 6-18.

Agisoft Metashape User Manual: Professional Edition, Version 1.6 - URL: https://www.agisoft.com/pdf/metashape-pro_1_6_en.pdf/ (дата обращения 19.05.2020).

Blanton C.M., Rockwell T.K., Contz A., Kelly J.T. Refining the spatial and temporal signatures of creep and co-seismic slip along the southern San Andreas Fault using very high resolution UAS imagery and SfM-derived topography, Coachella Valley, California // Geomorphology, 2020, v. 357, p. 1-21.

Holbrook J., Schumm S.A. Geomorphic and sedimentary response of rivers to tectonic deformation: a brief review and critique of a tool for recognizing subtle epeirogenic deformation in modern and ancient settings // Tectonophysics, 1999, 385, 286-306.

Johnston A.C., Schweig E.S. The enigma of the New Madrid Earthquakes of 1811-1812 // Annual Review of Earth and Planetary Sciences, 1996, v. 24, p. 339—384.

Keller E.A., Bonkowski M.S., Korsch R.J., Shlemon R.J. Tectonic geomorphology of the San Andreas fault zone in the southern Indio Hills, Coachella Valley, California // Geological Society of America Bulletin, 1982, v. 93, p. 46-56.

Kim W., Sheets B.A., Paola C. Steering of experimental channels by lateral basin tilting // Basin Research, 2010, v. 22, p. 286-301.

Kondorskaya, N.V., Shebalin, N.V. (Eds.). New catalog of strong earthquakes in the USSR from ancient times through World Data Center A for Solid Earth Geophysics. Colorado, USA: World Data Center A, 1982. 608 p.

Leeder M.R., Mack G.H., Peakall J., Salyards S.L. First quantitative test of alluvial stratigraphic models: Southern Rio Grande Rift, New Mexico // Geology, 1996, 24, p. 87—90. 
McCalpin J.P. Paleoseismology, 2nd ed. Academic Press, Elsevier, Amsterdam, 2009. 613 p.

Martin M.E., Bourgeois J. Vented sediments and tsunami deposits in the Puget Lowland, Washington-differentiating sedimentary processes // Sedimentology, 2012, 59, p. 419-444.

Miall A.D. (Ed.) Alluvial sediment basins: Tectonic setting and basin architecture // Sedimentation and tectonics in alluvial basins: Geol. Surv. Canada, Special Pub., 23, p. 1-33.

Peakall J. Axial River evolution in response to half-graben faulting: Carson River, Nevada, U.S.A // Journal of Sedimentary Research, 1998, v. 68, p. 788-799.

Rockwell T.K., Keller E.A., Clark M.N., Johnson D.L. Chronology and rates of faulting of Ventura River terraces, Cal. Geological Society of America Bulletin 95, 1466-1474.

Schumm S.A. Alluvial river response to active tectonics. Active Tectonics. National Academy Press, Washington, D.C., 1986, p. 80-94.

Schumm S.A. River response to baselevel change: implications for sequence stratigraphy. Journal of Geology, 1993, v. 101, p. 279—294.

Solovyeva M.A., Akhmanov G.G., Mazzini A., Khabuev A.V., Khlystov O.M. The Gydratny fault zone of Lake Baikal // Limnology and Freshwater Biology, 2020, №. 1, p. 368373.

Wilkinson, M., Roberts, G.,P., McCaffrey, K., Cowie, P., Faure Walker, J.P., Papanikolaou, I., Phillips, R.J., Michettii, A.M., Vottory, E., Gregory, L., Wedmore, L., Watson, Z. K. 2015. Slip distribution on active normal faults measured from LiDAR and field mapping of geomorphic offset: an example from L’Aquila, Italy, and implications for modelling seismic moment release // Geomorphology, 2015, v. 237, p. 130-141. 


\section{Подписи под рисунками к статье О.В. Луниной, А.А. Гладкова «Феномен}

разрывообразования в дельтовых отложениях мыса Рытый на северо-западном побережье озера Байкал (по данным аэрофотосъемки)»

Рис. 1. Структурное положение мыса Рытый и изученных современных разрывов в пределах района исследований. Разломы показаны по [Лунина и др., 2010 с изменениями], вдоль некоторых из них приведены собственные названия. На врезке - увеличенный фрагмент карты разломов с добавлением разлома «Р», предполагаемого по вытягиванию изобат, направленных в сторону меридионального сегмента поверхностных нарушений (см. пояснения в тексте). Внутри основного рисунка приведен механизм очага землетрясения по [Солоненко и др., 1993], ассоциируемого с образованием современной зоны разрывов.

1 - сейсмоактивные разломы, 2 - достоверные (a) и предполагаемые плиоценчетвертичные разломы (б); 3 - положение откартированных современных разрывов в дельтовых отложениях p. Рита; 4 - эпицентры исторических землетрясений по [Kondorskaya, Shebalin, 1982]; 5 - эпицентры инструментально зарегистрированных землетрясений с магнитудой $\mathrm{M} \geq 4.1$ в период 1950-2019 г. по данным Байкальского филиала ФГБУН ФИЦ ЕГС РАН (http://seis-bykl.ru/index.php, подписаны даты и магнитуды событий с $\mathrm{M} \geq 5.1$, произошедших в районе исследований в период 1908-1969 гг. в радиусе не более 100 км от современных разрывов на мысу Рытый); 6 - изобаты.

Рис. 2. Вид на мыс Рытый со склона на правобережье р. Рита.

Рис. 3. Упрощенный фрагмент геологической карты масштаба 1:200 000 [1974].

1 - современные отложения, представленные валунами, галечниками, песками, суглинками; 2 - верхнечетвертичные крупнообломочные отложения; 3 нижнепротерозойские метаморфизованные полимиктовые и кварцевые песчаники, гравелиты, филлитовидные и хлорит-кварцевые сланцы, сарминская серия, иликтинская свита, верхняя подсвита; 4 - нижнепротерозойские хлорит-серицитовые, слюдистокварцевые и амфиболовые сланцы, прослои метаморфизованных песчаников, сарминская серия, иликтинская свита, нижняя подсвита; 5 - раннепротерозойские интрузии, представленные мелко- и среднезернистыми биотитовыми и биотит-амфиболовыми гранитами с дайками плагиогранитов, муйский комплекс, III фаза; 6 - линия тектонического контакта, достоверная; 7 - линия тектонического контакта погребенная под молодыми отложениями и водой; 8 - зона милонитизации и катаклаза; 9 - граница нормального стратиграфического и интрузивного контактов, достоверная; 10 - изобаты. 
Рис. 4. Ортофотоплан мыса Рытый и его фрагменты с местоположением разрывов по данным аэрофотосъемки лета 2019 г.

1 - палеосейсмогенные разрывы, выраженные на поверхности уступами и линейными понижениями; 2 - современны разрывы в грубообломочных отложениях дельты р. Риты; 3 - место, где водоток уходит под землю 30.06.2019 г.

Рис. 5. Цифровая модель местности (ЦММ) мыса Рытый, детальный фрагмент левого борта р. Риты и гипсометрические профиля по линиям AB, CD и ЕF. Слева показана шкала высот.

Рис. 6. Пример определения параметров разломного уступа на профиле $\mathrm{G}-\mathrm{H}$, показанном на фрагменте ЦММ с отображением наклона поверхности от нуля (светлый фон) и выше (темный фон). Стрелками показаны разрывы субмеридионального сегмента зоны нарушений. Н2 - высота уступа по [McCalpin, 2009], ассоциируемая с вертикальным смещением (Throw) по [Wilkinson et al., 2015]; Heave - горизонтальная компонента полного смещения по падению разрыва, т.е. горизонтальное разобщение исходной поверхности по [Wilkinson et al., 2015]; $\alpha$ - угол падения эродированного разломного уступа (угол откоса).

Рис. 7. Роза диаграмма простирания современных поверхностных разрывов в дельтовых отложениях мыса Рытый.

Рис. 8. Обзорные аэрофотоснимки зоны современных поверхностных разрывов, сделанные 03.07.2020 г.: $a$ - субмеридиональный сегмент; 6 - северо-восточный сегмент.

Рис. 9. Гистограммы распределения параметров современных поверхностных разрывов: а - длин; б - количества разрывов с разными углами откоса уступов; в вертикальных смещений по разрывам; г - горизонтальных разобщений исходных поверхностей.

Рис. 10. Графики зависимостей между параметрами современных поверхностных разрывов: $a$ - между длиной и вертикальным смещением; б - между вертикальным смещением и горизонтальным разобщением исходных поверхностей.

Рис. 11. Фрагмент листа 8-Б атласа озеро Байкал (репродукция), иллюстрирующий положение действующих русел р. Риты на мысу Рытом в 1908 г. [Дриженко, 1908]. Значения глубин и высоты рельефа приведены в футах (ф). 


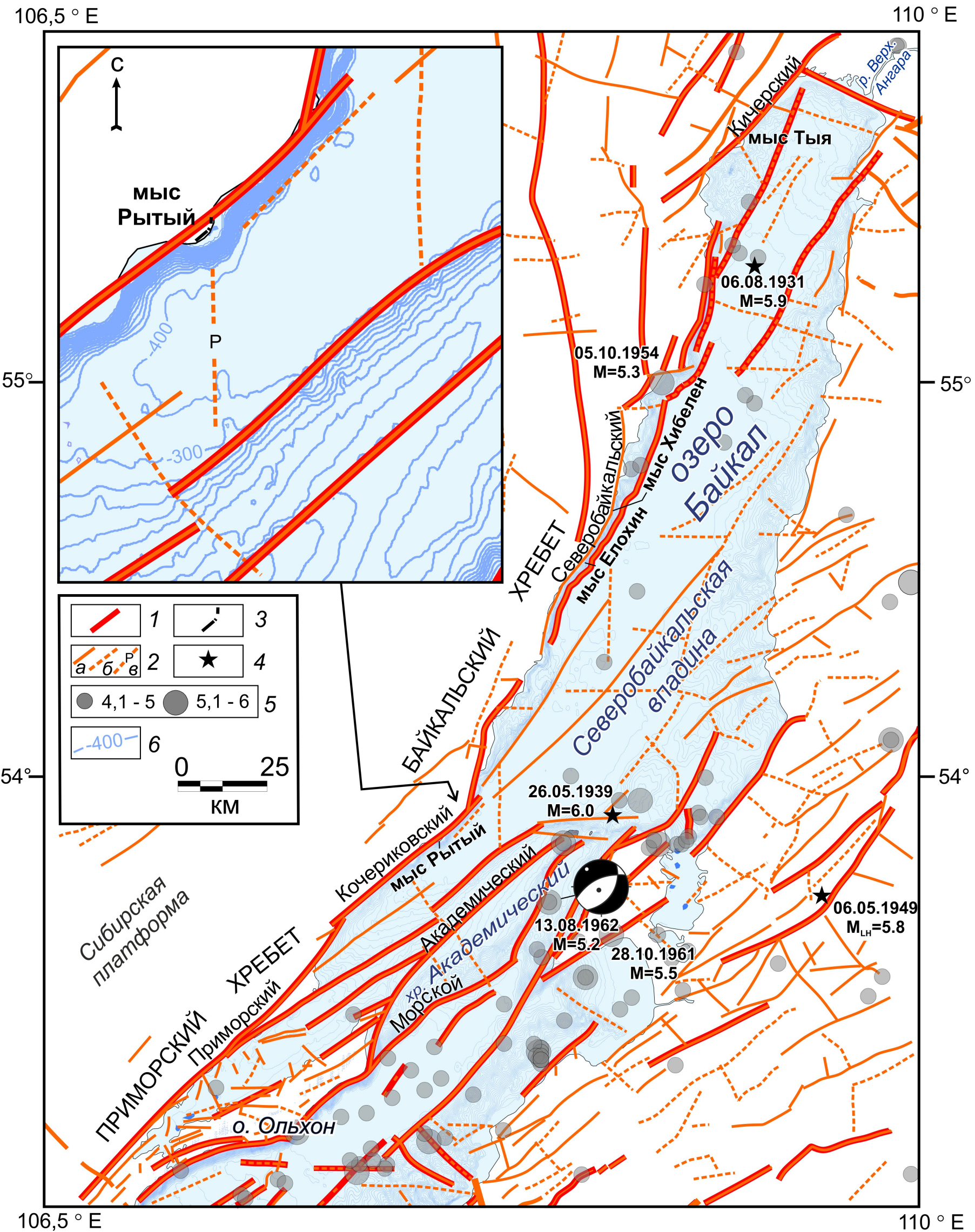




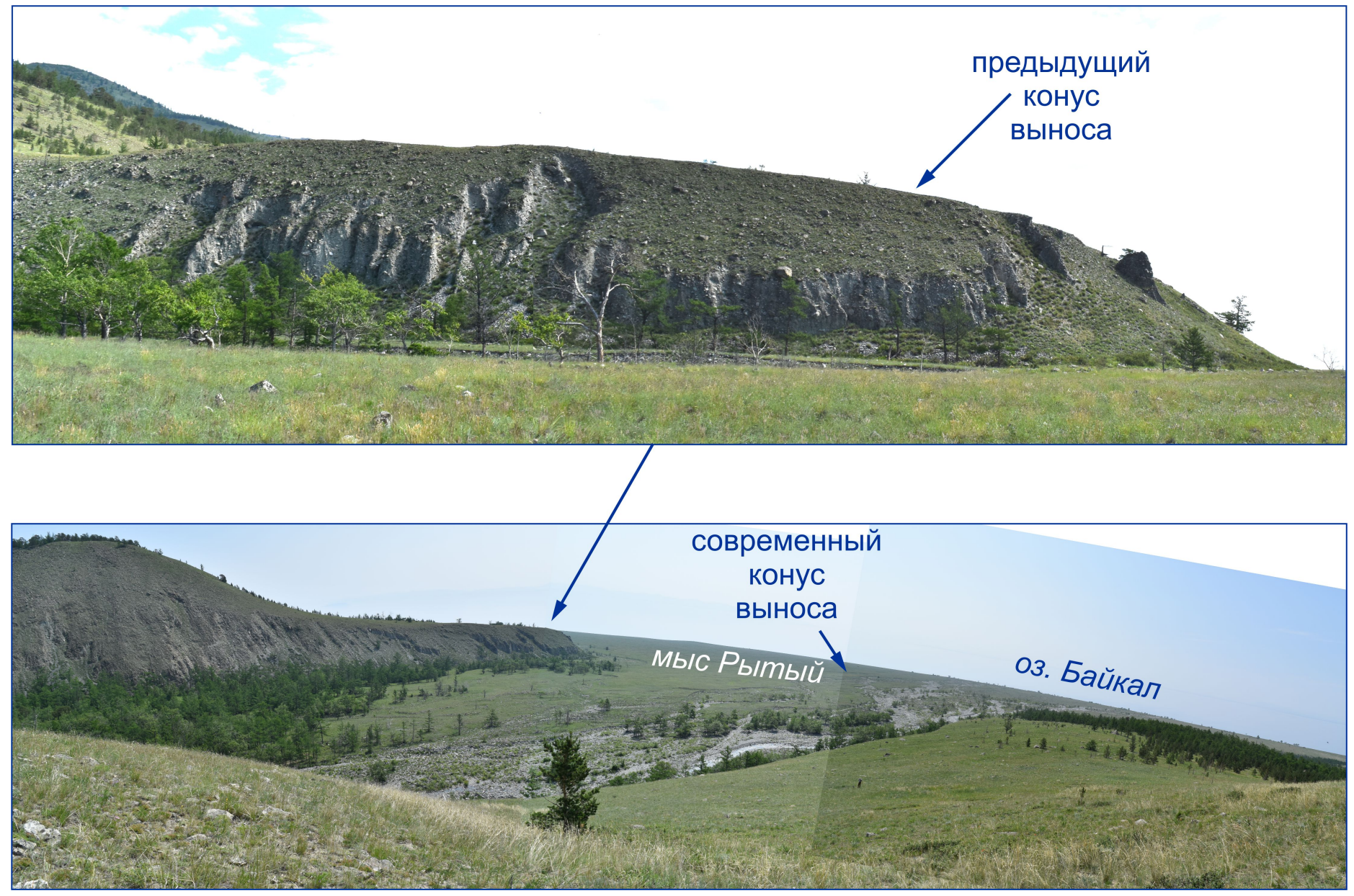




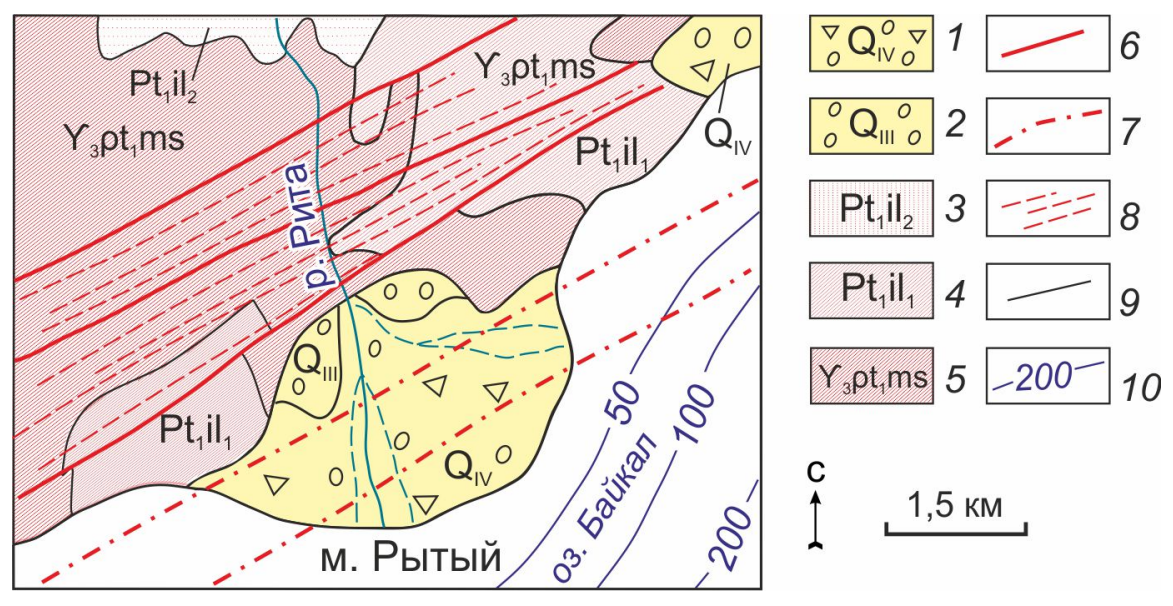




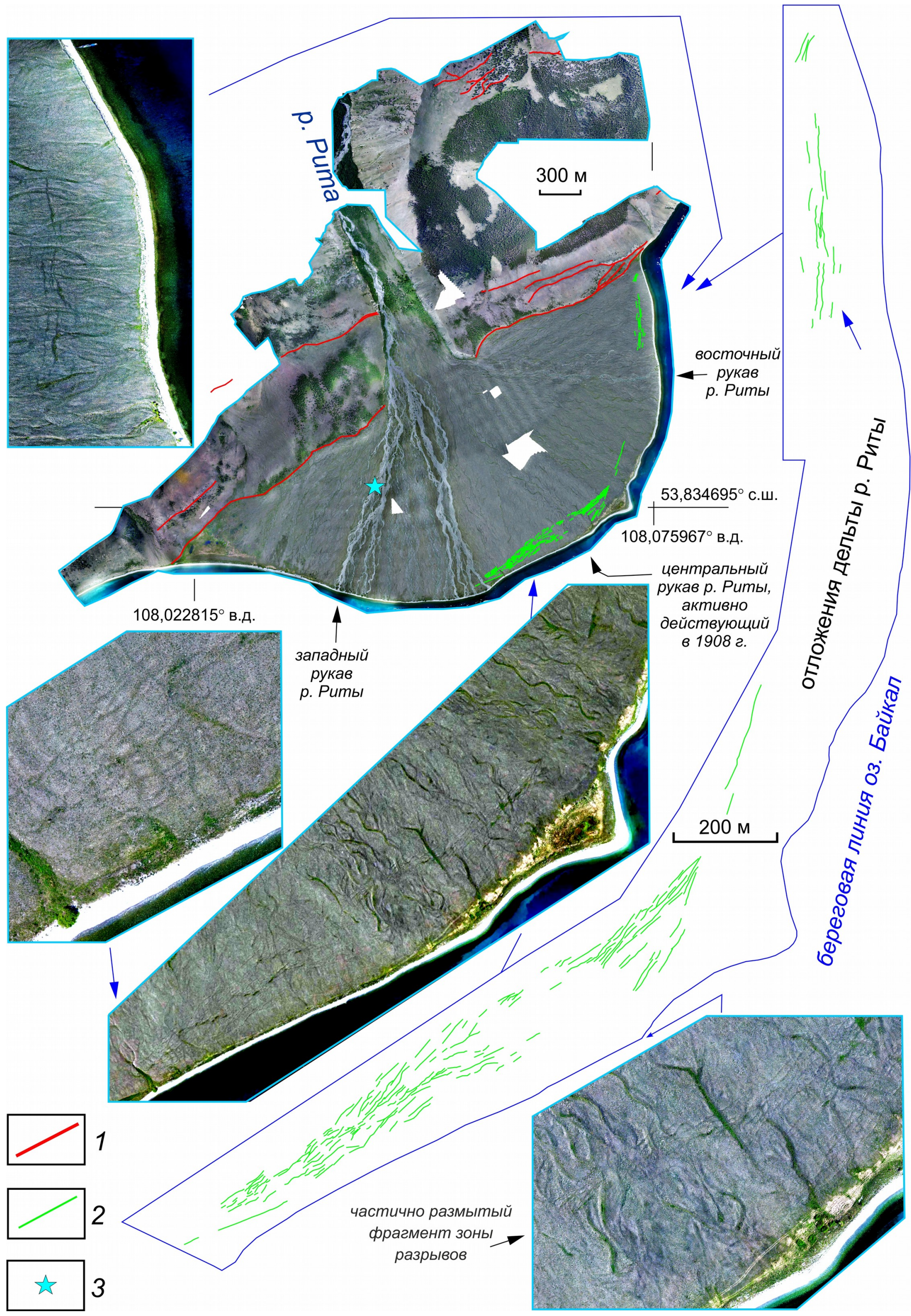



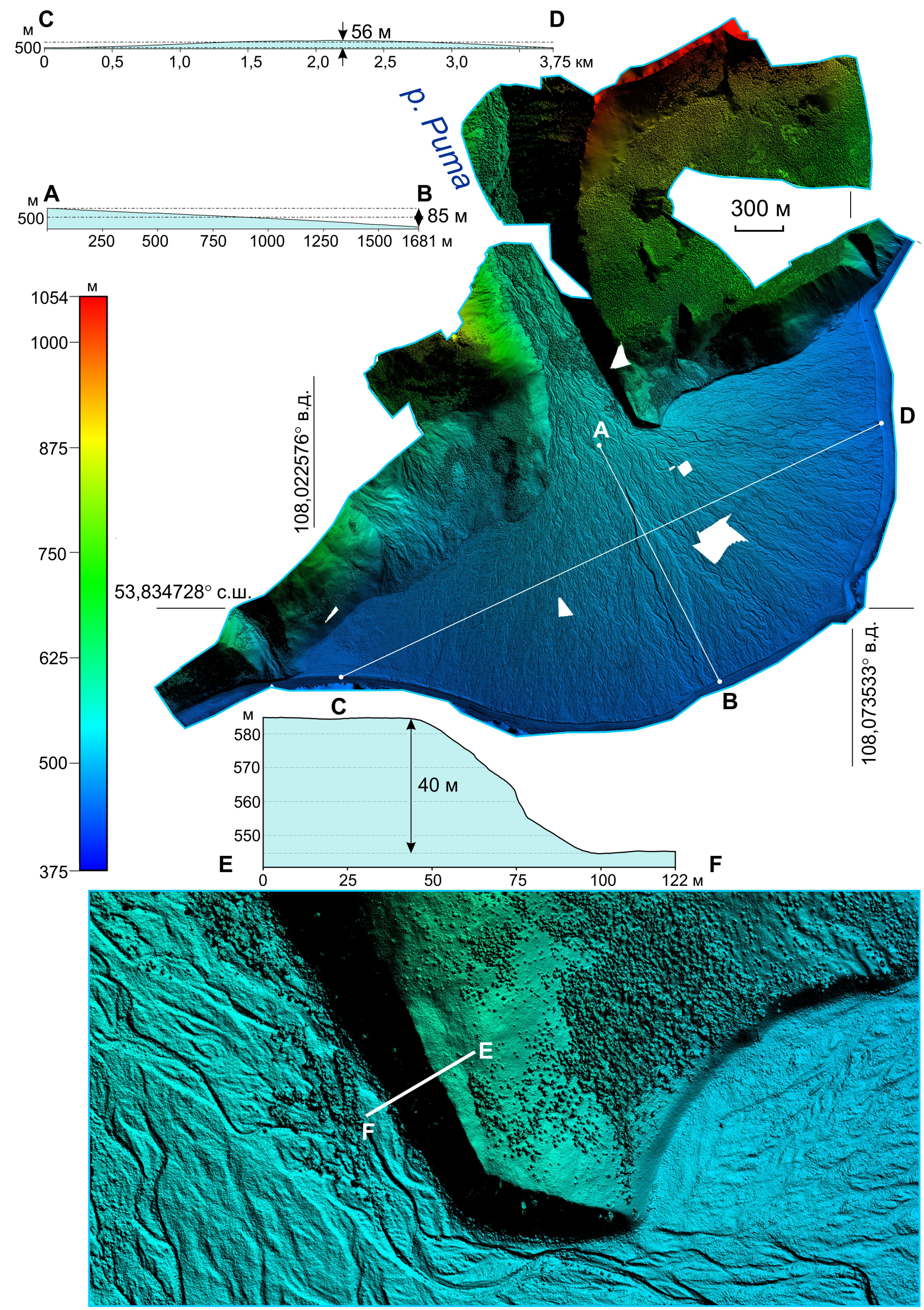


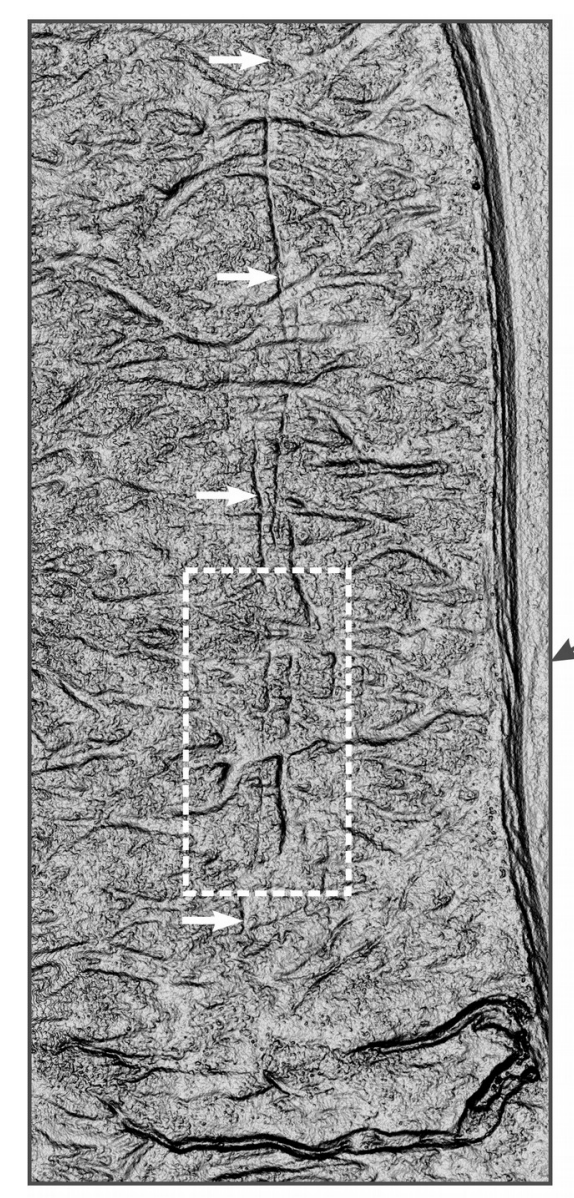

G $\quad 3^{\circ}$
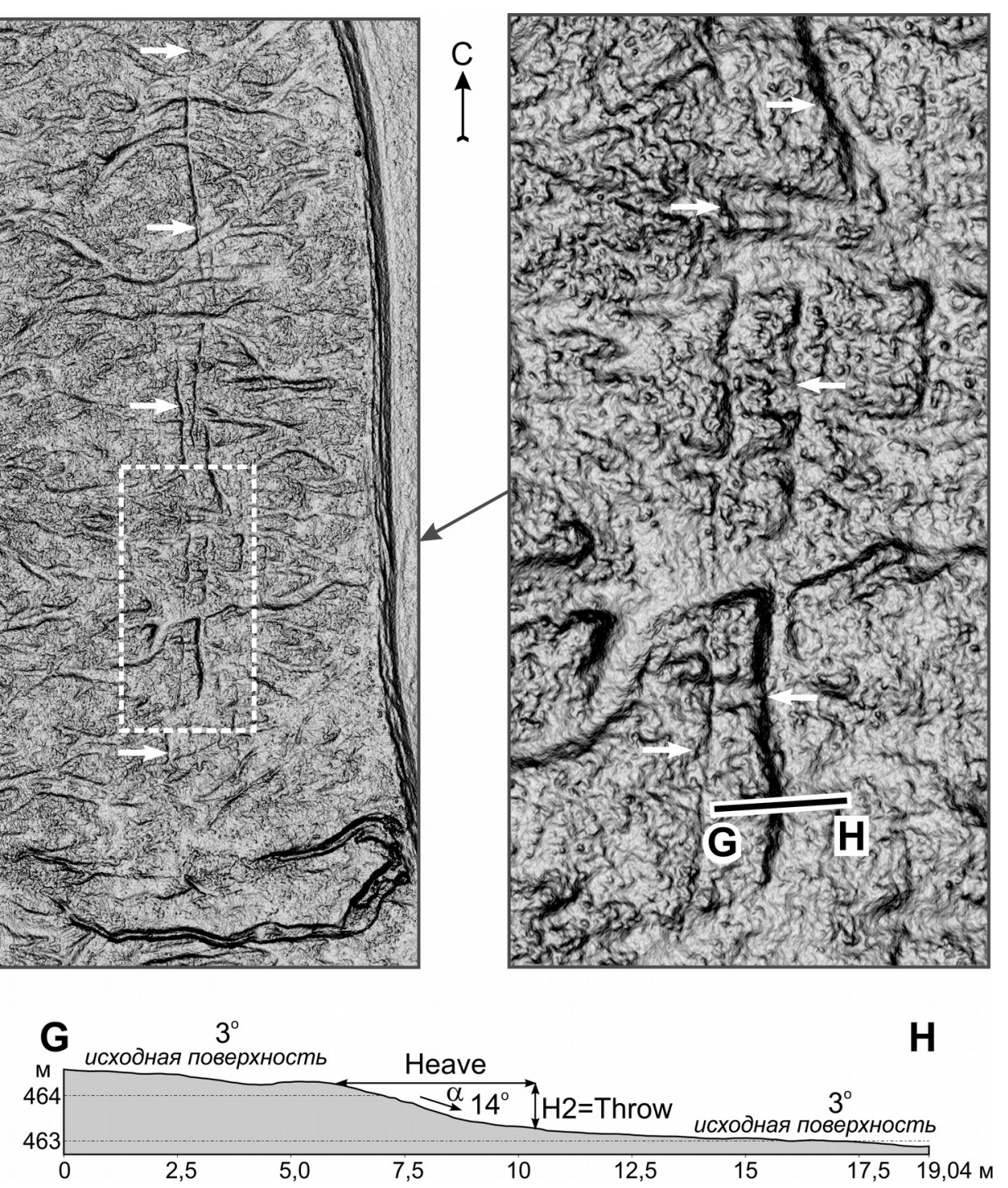

H 


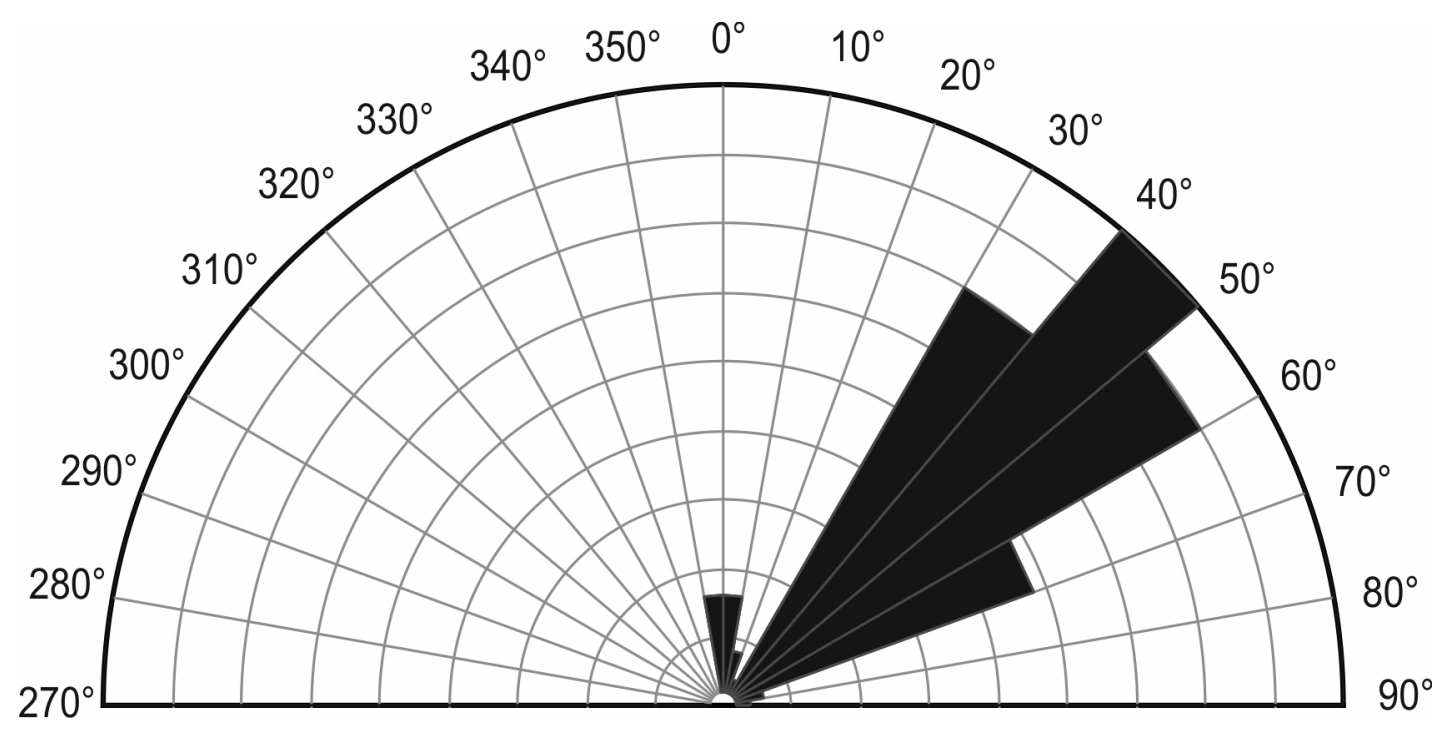



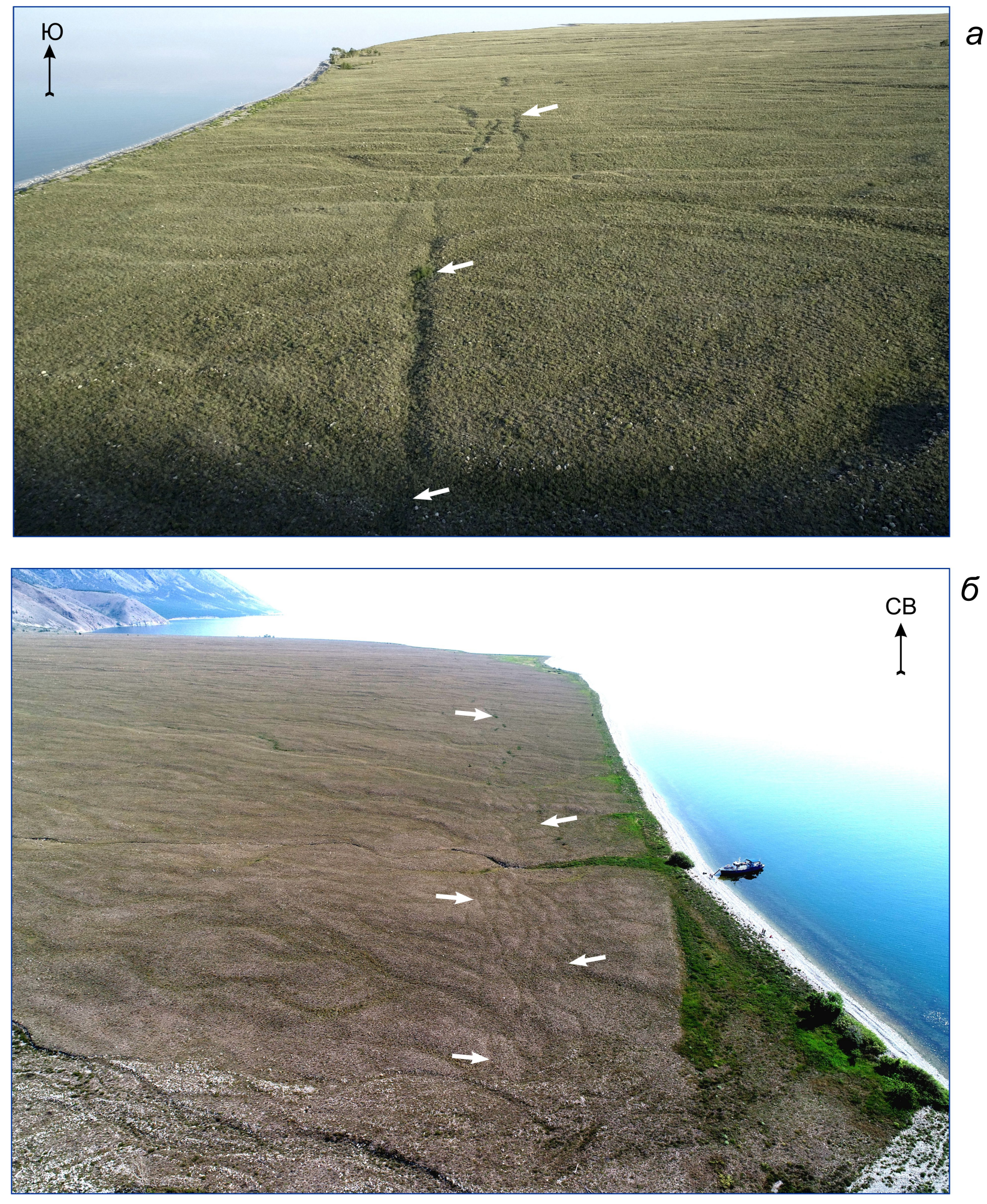

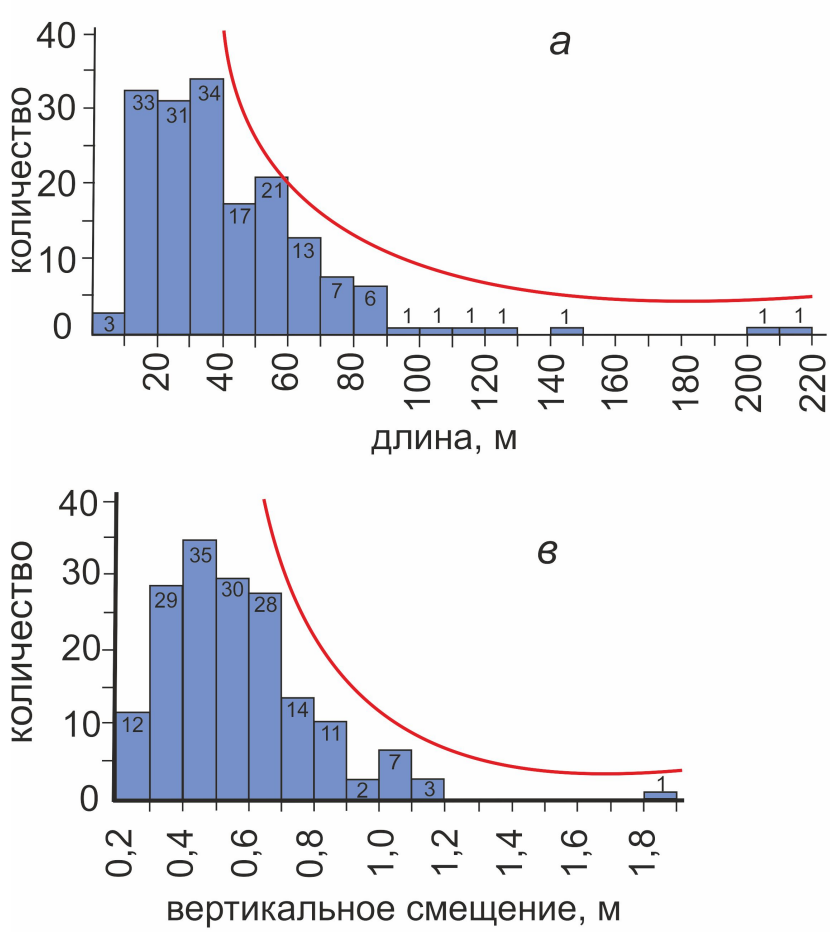
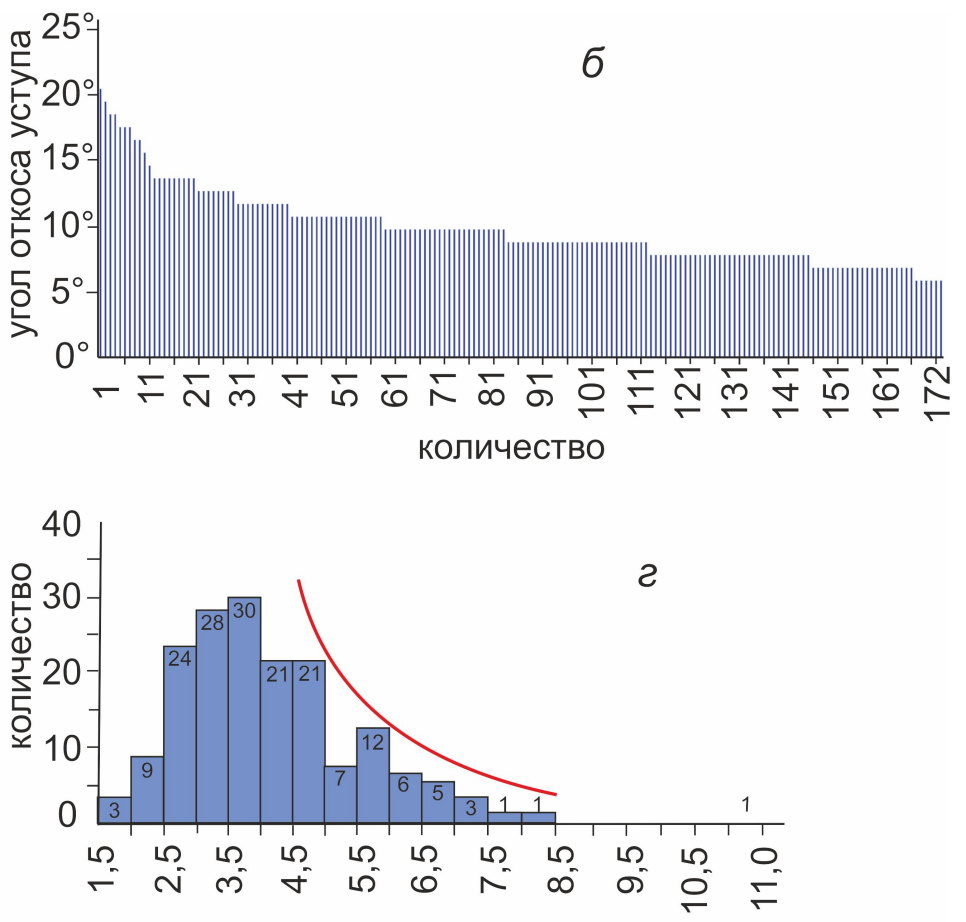

горизонтальная компонента смещения

по падению (горизотальное разобщение), м 


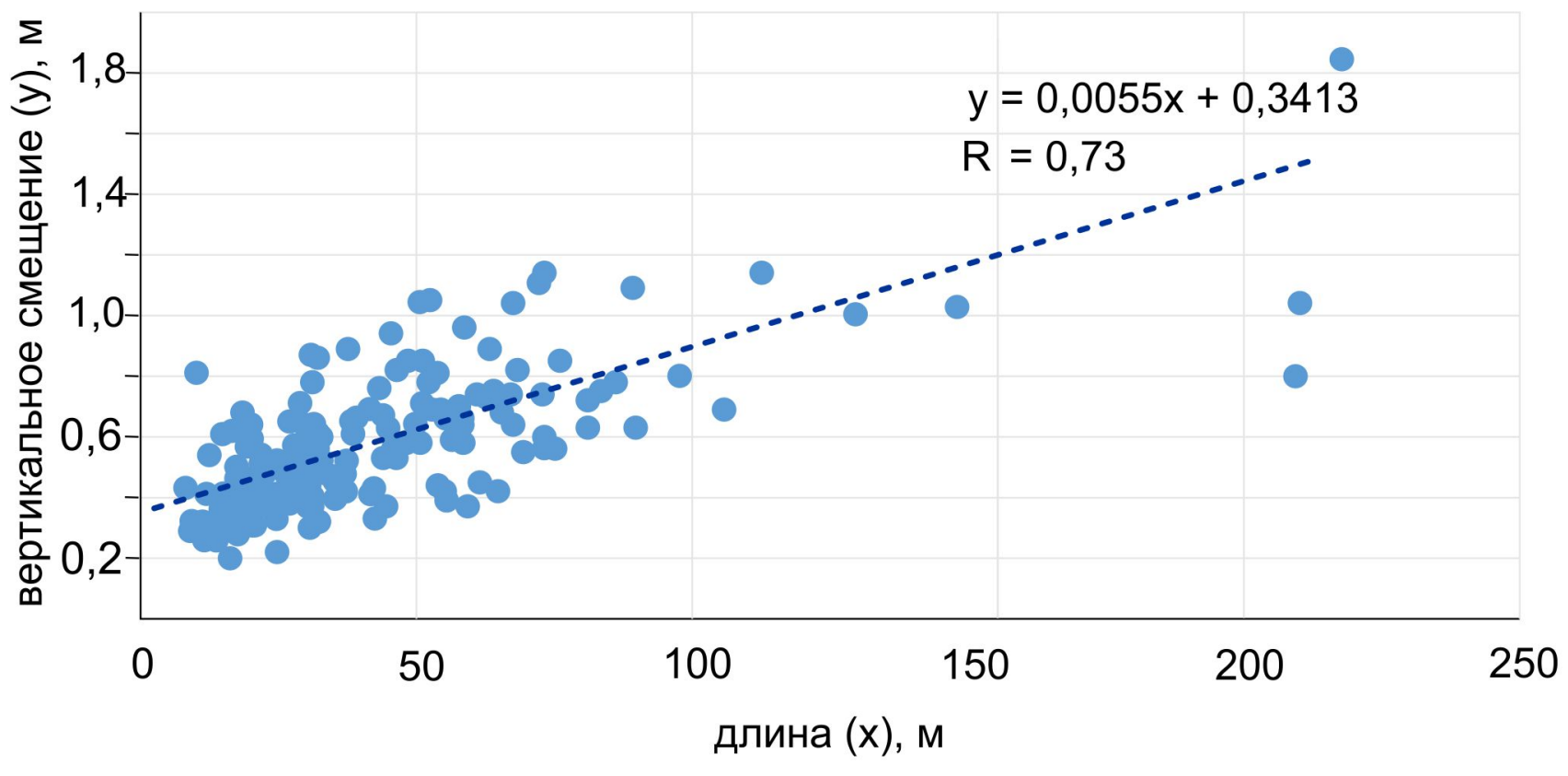

a

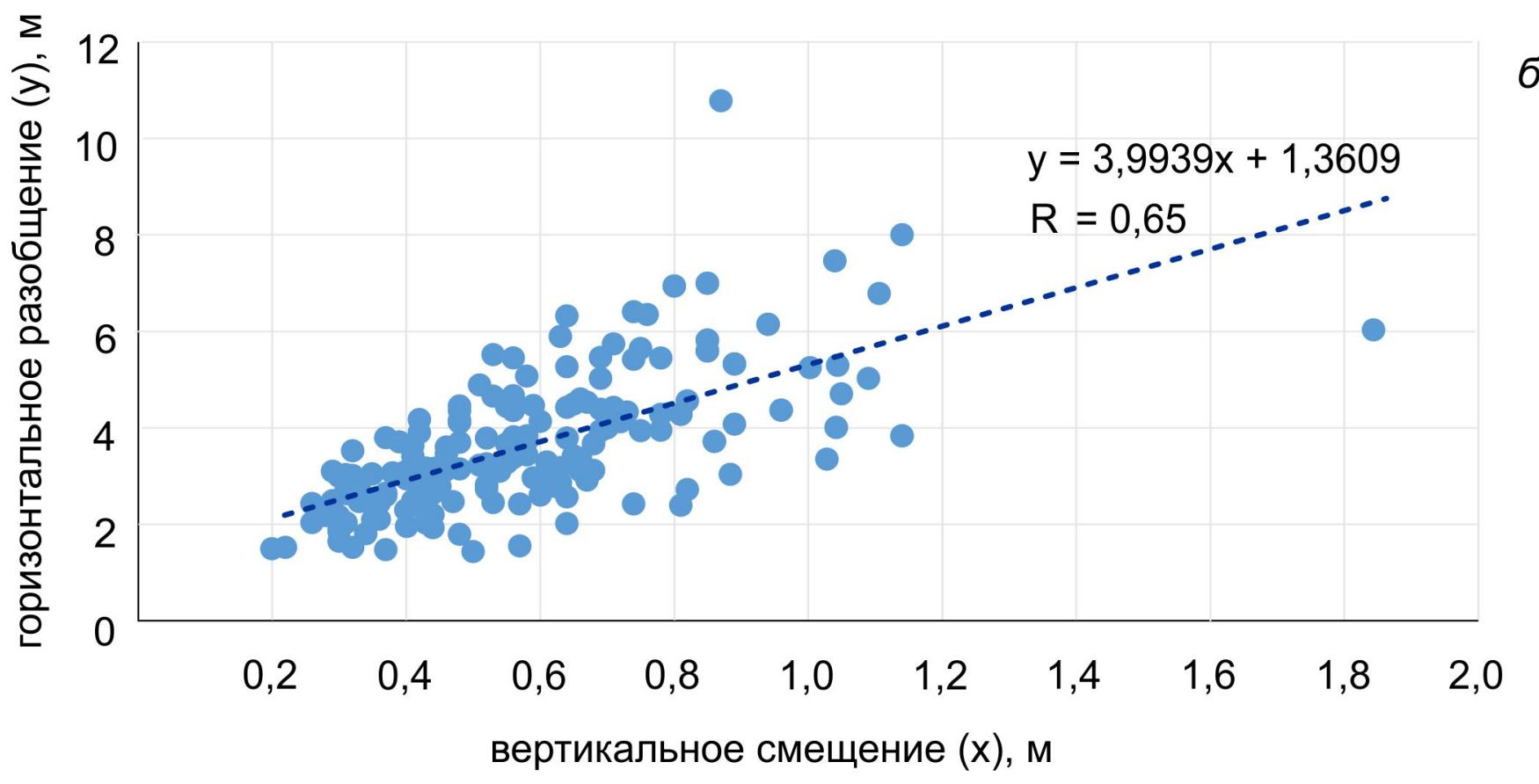




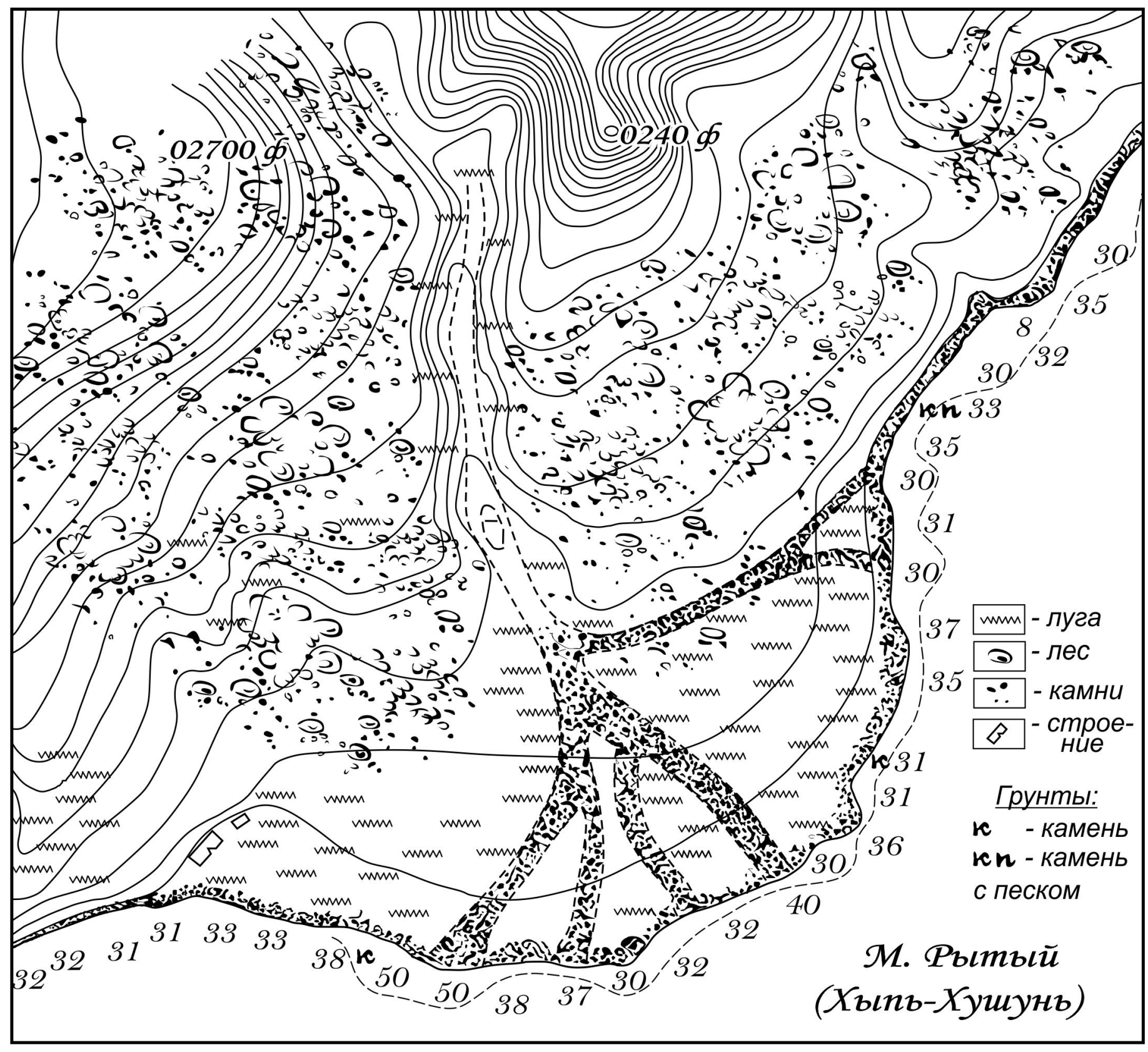

